\title{
Once Again, the Propagandist Media Played it Right and Won by a Knockout-Coverage of George Floyd's Murder Constitutes the Last Nail in Trump's Coffin
}

\author{
Aysar T. Yaseen ${ }^{1, *}$ \\ ${ }^{1}$ Faculty of Arts, The Arab American University, Palestine \\ *Correspondence: Faculty of Arts, The Arab American University, Palestine. E-mail: aysar.yaseen@aaup.edu
}

Received: September 28, $2020 \quad$ Accepted: December 3, $2020 \quad$ Online Published: January 10, 2021

doi:10.5430/wjss.v8n1p34 URL: https://doi.org/10.5430/wjss.v8n1p34

\begin{abstract}
At first it was the coronavirus briefings held at the White House and lead by the U.S. president Donald Trump. In these briefings and with the help of certain intrinsic and known-to-the public characteristics of the president's personality such as the love of power, authority and control, appreciation of dictatorship, arrogance, and self-aggrandizing, the media managed to portray the president as a person with modest or even poor communication skills, a bigot, a self-congratulatory, a liar, a self-opinionated, and a self-righteous. Second, it was George Floyd's murder as a result of the brutality of four white police officers in Minneapolis, Minnesota which overtook the nationwide pandemic, the coronavirus. Floyd's grievous death sparked waves of protests in major cities nationwide, and instead of standing up for his citizen's rights, Trump turned a blind eye to this heinous crime. Furthermore, Trump failed verbally and nonverbally to address the grieving nation and to show empathy and solidarity with the victim and his family. His words did not match the grave and horrific situation, and his voice tone and his facial expressions failed to pacify the irate public. The media outlets were there to expose Trump's deadly mishaps and glitches not just to the American public but to the whole world. With the help of the media, American people were able to detect the fallacy of his arguments and claims. These outlets were happy to dedicate hundreds of hours of live coverage in its quest to pave the way for Trump's demise and fall.
\end{abstract}

Keywords: black people, discrimination, propaganda, murder, Trump, brutality, protesters, detrimental

\section{Introduction}

The first blow Trump's administration received was the mishandling of the coronavirus pandemic. The president was fighting alone on a totally distinct frontline, namely, winning a second term regardless of the means to achieve this while the American public and the scientists were fighting on two other frontlines. The public sough freedom and a way out of the tedious quarantine, and scientists were behind financial gain. This pandemic widened the gap between the leadership and the public while differences of interest continued to accumulate. Coronavirus narrative was not really able to move the masses against president Trump, but it prepared the street for some sort of resistance. The killing of George Floyd took place at a right timing when the country was on the verge of explosion as a result of nationwide disapproval and disappointment with the Trump's presidency performance to mitigate and abolished the coronavirus. The killing further signaled the demise of Trump's leadership.

Protests stretched out to reach almost every major city in the U.S. Stories and events were unfolding in many places nationwide. Floyd's murder narratives were able to stimulate the public to take to the streets in massive protests against the leadership and its brutal apparatus, the police force. Large crowds marched to the streets because they felt it is the true time to make a difference. Change on race is difficult to achieve, and hundreds of years of racism are not going to be obliterated in a wink of an eye, but Americans realized that their leadership symbolized by a president who on every occasion nurtures racism, hate and the use of excessive force against unarmed minorities and the powerless must be put out.

The media purposefully gave momentum to Floyd's case in the midst of shaky leadership. On the one hand, the media managed to create two diverse images; the first represents the good side of the story, and to consolidate this 
image, media outlets interviewed people who contributed linguistically, financially, and emotionally to Floyd's case. On the other hand, the media succeeded in portraying Trump as the evil side of the story; he is being reckless, emotionless and a person who failed to show empathy and solidarity with the victim and his family. Above all, a person ready to kill his own people as he threatened to deploy the military in major cities nationwide.

\section{Propaganda}

Propaganda is defined as a deliberate attempt to persuade people, by any available media, to think and then behave in a manner desired by the source; it is really a means to an end. The methods employed vary according to the communication media available. Methodical and planned decisions to employ techniques of persuasion are designed to achieve specific goals that are intended to benefit those organizing the process. Essentially, propaganda is really no more than the communication of ideas designed to persuade people to think and behave in a desired way, and the word "propaganda" continues to imply something evil, (Taylor, 2003).

In times of crisis, when passions and emotions are high and are thus more susceptible to manipulation by powerful apparatuses as propagandist media, influence emanates from the power of the these institution to change any future behavior of the masses (Boyd-Barrett, 2003a; Kellner, 1992; Knightly, 2002). Media power lies in its capacity to shape public feeling while appearing only to express it, (Downing, 1980). Emotional language, creation of associations and connotations, repetition and simplification of reality are the key elements of propaganda (Mesthrie et al., 2009).

Adolf Hitler summarized the art of propaganda in Mein Kampf as: Its [propaganda's] effect for the most part must be aimed at the emotions and only to a very limited degree at the so-called intellect . . . all effective propaganda must be limited to a very few points and must harp on these slogans until the last member of the public understands what you want him to understand by your slogan, (Pratkanis \& Aronson, 1991: 250-1).

As defined above, propaganda depends mainly on the susceptibility of the human soul to effect influence and change as it targets the emotional side of people. It is very important that the propagandist knows whom to target, where and at what times.

\section{Intertextuality}

Intertextuality subsumes the ways in which the production and reception of a given text depend upon the participants' knowledge of other previously encountered texts (Beaugrande \& Dressler, 1981; Fairclough, 1992). Shared knowledge or old knowledge, agreed upon by members of a particular society especially historical events that constitute cultural and national identity, constitutes the basics for intertextuality; interpreting and perceiving present events depend completely on understanding past experiences and the ability to link them to present occurrences, and the interpretations of these events of today are not possible without comprehensive knowledge and understanding of history.

\section{Positioning Theory}

According to the positioning act of the position theory, someone might be positioned by others or has positioned himself. In both cases, this positioning involves the attribution of qualities of character, intellect, or temperament, sometimes supported by biographical reports on the past behavior of the person in question (Davis \& Harre, 1990). Furthermore, the positioned person is assigned or denied certain rights and duties for the sake of performing certain sorts of acts, thus constraining what he can rightly do or say (Harre, et al., 2009).

According to positioning theory, a public figure, a president for example, has to be more socially engaged and sensitive to domestic as well as international issues. Assignments of rights and duties to a person depends on prior evaluative descriptions of that person. Making use of the positioning theory, the media managed in portraying Trump as a socially disengaged leader while evaluating his response to two concurrent incidents, namely, the coronavirus pandemic and George Floyd's murder by an apparatus (the police) supposedly considered governmental under the supervision of the president.

George Floyd's murder must have placed Trump as the elected president in positions where he can act quickly and to the purpose anticipated by the American public. Being selfish, hesitant, overbearing, unsympathetic, self-absorbed, self-proclaimed, a person who lacks empathy, a man who truly does not care, and offensive cannot be the relevant 
personality trait appropriate for current emotions-wrecker situation.

As it is mentioned earlier, one either positions himself or is being positioned by others. The propagandist media succeeded in positioning president Trump according to a well and carefully studied plan for the sake of tarnishing his image. In addition, the propagandist media successfully managed to show the worst of Trump in countless occasions, for example, when threatening to deploy the military, when clearing the streets near the white house by the use of excessive force for the sake of photo op, threatening to use vicious dogs against the protesters, calling the protesters "terrorists", and so forth.

\section{Rhetorical Functions of Going Public}

Presidential communication matters and makes difference. Beyond any doubt, presidential communication is a vital and crucial element of modern American presidential politics especially in the midst of exponential growth of the apparatus of presidential communication in the White House Office (WHO). No one denies that all American presidents in general and modern presidents in particular devote more attention to communication especially in time of national disasters and issues that are alike. Culturally, Americans simply expect presidents to communicate often and at great length about every public issue of the moment even if formalities of the office are not strictly applied, (Ryfe. 2005).

(Kernell, 1997), argues that presidential power which relies mainly on presidential bargaining for agendas to go through operates on a two-tiered track: first along the line of the president's reputation within the Washington Community, and a second according to the president's public prestige. (Kernell, 1997) contends that in the "going public" model, Presidents rely upon public opinion for their leadership in Washington. And this may draw the blue print of their political future and leadership.

For the rhetorical presidency model, however, going public maybe perfectly rational even when it is not especially useful for individual presidents. On its terms, all modern presidents must go public because the idea of presidential rhetoric has been institutionalized as a taken-for-granted norm in modern politics. This expectation, in other words, exercises a certain force on presidential behavior. Even if it is not a winning strategy, and even when particular presidents express discomfort with it, presidents go public because not to do so risks seeming "unpresidential." For (Tulis, 1987), this idea - that the presidency ought to serve as a primary source of legislative and deliberative energy - represents nothing less than a "second constitution" in American politics - a layer of understanding about how the constitutional system is supposed to work that has been overlaid on to the original, founding conception.

(Crockett, 2003) argues that according to the rhetorical presidency model, there is a symbolic dimension of presidential rhetoric in addition to moving and affecting the public opinion, and presidents seek to reinforce and consolidate this. This is made possible by meeting the demands of the masses. Going public serves an important systemic function. By doing so, presidents propose and campaign for policies because Congress and every other political institution is ill-equipped to do so since not every person or institution has access to media outlets. Going public then plays a major role in initiating and defining policy agendas. Individual presidents may go public to win legislative victories. However, the larger purpose of going public is institutional — the political system demands that presidents set and frame public and policy agendas for the sake and the welfare of his political party and political future.

When the president fails to do so, i.e. going public and socially engaging with the masses to sell his political agenda as one major theme among other themes, political suicide may seem inevitable and unavoidable.

\section{Analysis}

In George Floyd's case, propagandist media made use of the political rule of "going public" as a norm in modern politics to persuade and evince political and social change. In order to achieve this and to effect persuasion, media made use of several persuasive techniques. The following are some of the techniques used in reporting:

First, the people interviewed: The overwhelming majority of the people interviewed were black people. In addition, some media outlets, CNN for example, largely increased the number of its black reporters and correspondents. This is a double-edged sword in the process of persuasion. On the one hand, the media wanted to consolidate the idea of the "two sides of the story" and the "debate format" to initiate the fight and to create the "presupposed" balance in reporting, and the result is paying more concern to this "assumed" balance rather than informing audience of the truth, (Tannen, 1998). On the other hand, the media sought to show to the world that this deeply rooted problem in 
America, namely, discrimination is still alive, and that black people are oppressed by the leadership. The choice of interviewed black people was purposefully and strategically done. The media categorized interviewed black people into seven major categories. These categories are:

The first category was the common young black men and women. These are mainly participants in the daily protests, and their voice must be heard to give momentum to the future and escalated protests. These people can speak up their minds freely and without constraints or censorship. They can openly call for more violence, destruction, burning buildings, use foul language, and dispose and expose the real situation in which they live. All in all, they have a huge repertoire available at their disposal. These people were interviewed at the outset of the protests, and they are used as a spark to feed and escalate the protests and keep them going, so it very important that media outlets started with the people in the streets.

The second category was the black legal analysts, political analysts, criminal attorneys, black attorney generals, black mayors, black police chiefs, and legal experts. It was so vital for the media to interview this group as it is the group that gives legal consultation for the protesters in the street. In addition, it was able to emphasize legal rights and malpractices represented by the police brutality, the abuse of power, and that the police acted out of malice. This group was able to scan the black history and the hardships black people experienced in America. It was also able to explain the biases of the legal system in the country represented by the police brutality and the use of excessive force against the African Americans. This category's major role is to instill in the communities of color a belief of having two distinct justice systems. Former South Carolina House member Bakari Seller commented on Obama's speech where he said that Obama's speech reminded him of Martin Luther King's Jr. speech "I have a dream". CNN interviewed this person many times during the protests where one can sense a call for revolution and more protest in his language. He added that what is going on today is a reminder of a bright history when we abolished discrimination against black people. Comparing Obama with Martin Luther King Jr. carried an embedded message for pursuing new leadership and getting rid of the present one since Obama was a two-term former president accepted by the majority of people.

In this regard, the media kept on adding insult to injury. These outlets targeted black guests by questions that aimed to instill suspicions of the judicial system. They asked rhetorical questions such as "How many times a police officer was convicted in Minnesota?" Furthermore and for the same reason, hypothetical questions were also asked such as "What are the chances of getting a conviction in Floyd's case?"

The third category was the black intellects. University professors, authors, and thinkers were interviewed for the sake of giving the protesters participated in large demonstrations coast to coast familiarity of their past as slaves. Their job was mainly to give logical ideas to match the current situation as well as to remind the black people of their history, hardships, fight for freedom and emancipation, and the systemic oppression of the black people by their leadership. For example, Eric Dyson, professor of sociology at George Town University and author of "what truth sounds like", condemned policing of black people and accused the leadership of depleting black persons of resources and depriving them of life. He further urged black crowds to continue to fight for justice and civil rights. Cornel West, professor of philosophy at Harvard University was also interviewed where he gave his perspective on what is going on and urged protesters to continue their fight as they have suffered for a long time and paid hefty price during long history of enslavement and injustice.

The fourth category was the religious figures represented by reverends and pastors. Black religious leaders were interviewed heavily by the media outlets since they constitute the spiritual influencers. They accused Trump of hijacking religion for political reasons. They criticized the leadership and the way the police forcibly removed protesters from around the White House to clear the path for Trump, his assailants and his team to get to the church for a photo op. Trump stood still in front of the burnt church holding the Bible up-side down not knowing what to say. This triggered protests from his closest allies and religious leaders as well. The whole idea of going to the church for a photo op is perceived as heresy to most officials in the United States. Most military personnel attacked the protesters around the White House were from bureau of prisons which means that the White House is guarded by prison guards from different states especially from Texas. The religious leaders did not like this and accused Trump of dividing the nation.

Reverend Al Sharpton, president: National Action Network argues that what happened to Floyd has been happening for all black people for decades, and it is happening every day in America. He addressed the black congregation saying it is time to stand up and time to set the police knees off our necks. Reverend Jessee Jackson was interviewed where he insisted that the protest is a good way to start and that voting guarantees the change; he later visited the killing place and assured the continuation of the protests to gain rights and equality. 
The media showed Trump's image in front of the church in Washington D.C. over and over. Furthermore, claims that Trump never been to a church were made public and repeated many times by the media. CNN called that day "the horrible day, last Monday when Trump cleared the White House area for a photo op". They added that Trump was born to privilege because he was able to start his business since he inherited tons of money from his father. This came in the context of "as a rich man, president Trump does not need to pretend being religious".

The fifth category was the black celebrities. These people are influential in the American life since they are rich and famous. Their discourse can easily instigate and bring about change in black communities all over the U.S. They were used by the media to consolidate the idea of inequality and injustice among black protesters and that change is a priority and aspired goal. Kareem Abdul-Jabbar, NBA Hall of Famer, for example, called for social change and that protesters across the U.S. demand social justice. He added that discrimination is deeply rooted when he recalled how the word found wide spread and circulation in society during his childhood. Michael Jordan, NBA superstar and Hall of Famer, expressed his support to the protests, and his generous contribution of more than 100 million dollars to support civil rights and social justice received acceptance and admiration from wide sectors in the society. Other celebrities contributed financial, emotional, societal, civil, and communal support while president Trump and his abusive leadership were totally absent from the public scene as civil servants elected by the public to serve the public.

The sixth category was black civil rights activists. This group is important for the continuation of the protests. Their job is to teach black youth old experiences in history. They also familiarize the youth in the street with similar encounters happened in the past with the governmental apparatuses such as the police and how they reacted to them so protesters know what to do in similar cases. Furthermore, their job necessitates familiarizing protectors with their rights.

Some black leaders and activists clearly justified some protesters' behaviours such as looting and violence. Some declared that the only way for oppressed and suppressed people is to revolt and resist. Tamika Mallory, a black female activist who represents the youth movement in the protests consolidated the "us" vs. "they" division or dichotomy. She accused the white leadership of being looters. She said addressing the white leadership: "do not talk about looting; you taught us looting. America looted black people and native Americans; the black people learned looting and violence from the white people". Tamika argued that buildings are burning because of the systematic preserving of white nationalist and white supremacy; buildings are burning not just for the death of George Floyd; they are burning because people in Minnesota say to people all across this nation enough is enough. She further warned the government and leadership from challenging young black people in particular, and that young people will respond as they are in rage. The only way to stop this state of emergency is to arrest the cops not only those who brutalized Floyd but also all cops everywhere in the U.S. who committed such heinous crimes in the past where black people were being murdered. Tamika indirectly defended all types of misconducts by black people during and before protests such as looting, destroying police cars, and burning down buildings on the pretext of happening as a natural reaction to the long-term injustice and oppression by the whites.

The media in almost all cases focused on black looters to instill the idea that they are the ones who are oppressed and mistreated by the government represented by the police. Youngsters who damaged and sat the police cars and cruisers on fire were black in almost all shown images. As reported, some black activists went even further to say that looters of T-shirts and other items do not deserve to be killed, and that the entire police force is corrupt.

As a result of this intensive coverage of black activists' perceptions regarding this crisis, it is evident that these activists appear to have command of protests.

The seventh category which was perceived as the most influential and important to the protesters and the most detrimental to president Trump was the appearance of former president Barak Obama in the media to address the nation. His appearance further isolated president Trump and his leadership. For a short period of time, the American public got the sense that their real president is addressing them, and they have to listen. Obama greatly valued the spontaneous response to police brutality and lack of justice by young people. He added that so many young people were activated to deal with this incident, and this is encouraging. He further called the last few days "tragic", and that people are being awakened. Obama described the protests as something different, and that they can be sustained over a long period of time. Trump's predecessor praised the protests and called on the American youth to play a constructive role for change while he is appearing as the real leader of the country in the complete absence of Trump's leadership. During the interview, CNN anchor kept on calling Obama "Mr. president" in clear recognition of his role as a president and a sign of denial and unrecognition for the incumbent president. This showed the extent to which the American people are yearning for real leadership. For them, Obama's interview represented a call for 
overthrowing of Trump's regime especially at this time where the presidential elections are few months away. Obama quoted saying: "make people in power uncomfortable" in his interview. CNN emphasized this quotation by repeating it over and over asking colored leaders about the connotational meaning of this statement. The statement may mean forcing people in power to listen and respond to the people in the street or a call for public disobedience to oust president Trump via the use of power.

Interviewing the former African American U.S president Barak Obama was so damaging to Trump's leadership. It is considered by many as the canon for the aspired upcoming future change of leadership. This interview sat the basic tenets and precepts for future organized protests hoping for ousting the leadership as a preliminary demand for future political and social change. At this critical time, the American public wanted to hear and to listen to the voice of reason. American people who already lost faith in Trump's leadership and are convinced that the country is in a state of anarchy caused by the absence of real government perceived Obama's speech as a means that lift up their morals and spirits and that there is still hope for change.

Obama's words were echoed and repeated by the media to achieve the aspired goal. They found circulations almost in all media outlets in the U.S. and abroad.

Second, the dedicated coverage time: media outlets were not reluctant to devote hundreds of hours of live coverage of the incident. During these times, selected images, selected news items, and selected interviews were repeated and highlighted over and over during news bulletins and news programs.

Third, focusing on the raised slogans: raised slogans by the protesters received special attention from the media. Slogans were under scrutiny and focus throughout the days of protests. These slogans carried strong messages for the leadership as they used powerful language and emotive language as well. Most famous slogans in these protests were: "black lives matter", "I cannot breath", "charge them all", "stop police brutality", "no justice, no peace", "silence = violence", "white silence is violence", and so forth. Media cameras put these slogans carried by protesters under spotlight even in toughest situations such as when protesters were attacked and chased by the police.

Fourth, the use of emotive language: interviewing Floyd's relatives (Floyd's son and daughter, his daughter's mother, his brother, his grieving girlfriend) was also managed carefully by the media. When Floyd's daughter spoke for the first time, she said "I miss my dad". This is very strong and influential use of language. Emotive language, shedding tears and sobbing, expressive facial expressions, body language, voice tones were all weapons used by the media to denigrate Trump's leadership. The media in this regard focused on addressing peoples' emotions apart from their intellects so they can achieve the aspired goals and intentions. The media managed to evince a strong desire for reconciliation, politically and socially. The media succeeded in exposing Trump's briefings and comments as devoid of empathy, warmth, and feelings. Trump's verbal and nonverbal dexterity lagged far behind his political competitors as well as black activists and civil rights leaders.

Fifth, media made use of one important standard of textuality, namely, intertextuality. The media succeeded in using intertextuality when referring to past shootings of black people by the police and linked them to what is going on at present time. For example and on many occasions, CNN showed pictures of tens of black people who lost their lives to police brutality and the excessive use of force. The media used techniques to bring back images and excerpts of language from past events. Among these techniques was the use of "historic present" where the present tense was used to describe past event as if they are taking place now. This use is a manipulative technique used by the media, and is used to add dramatic effect to these past events and link them to the protests of today. Both events appear as happening concurrently at the time of speaking.

Sixth, official Trump's proponents who opposed his present actions were interviewed and their discourse found circulation in society by the help of the media. The media managed to break apart this seemingly Republican stronghold coalition and its allies that supported the president's policies for a long period of time in the past. Trump's extraordinary and unprecedented actions and policies were severely reprimanded by the media and the allies as well. The media shows how Trump has been repudiated by his own team members and military leaders.

When special operation teams from prisons in Texas and other states, military, police force, and national guard were all called in and relocated to put an end to the protests, the secretary of defense, Mark Esper admitted on June $3^{\text {rd }}$, 2020 that there is no need for all these forces at this time. He tried to distance himself from the president's threats and insisted that it is a mistake to call in all this force. Esper described the security barrier around the White House which includes federal law enforcement and correction officers an overreaction by the president. To distance himself further from the president, Esper later denied knowledge of where the president and his team were heading when going to the church for a photo op. Then after that he expressed his disapproval of the action while insisting again 
that it is not the time to call in the military to stop the protests. Former secretary of defense James Mattis described Trump as a threat to the constitution. He declared support for the protesters, broke up with the president, and accused Trump of dividing the nation. Mattis declared clearly that Trump does not even try to unite the nation; on the contrary, he is trying to deepen and to consolidate the ethnic, religious and racial differences and eventually, strengthen the division among Americans. He also declared that American people can unite without Trump and his team. He further compared Trump with Hitler when Trump raised slogans similar to those of Nazi Germany, such as "we have a powerful national guard"; "using the military to dominate the streets"; the president used the term "dominate" as an indication of power and authority, and that he is the omnipotent and omniscient; "the nation does not need healing, but it needs law and order"; he claimed in an interview. Instead of calling for healing and reconciliation at this crucial time, he insisted on using power and suppressing the public opinion.

Seventh, The media managed to portray the president as a stubborn person in the negative sense of the word and as a person who cannot differentiate between what is real and what is unreal. A person whose mental abilities are equal to those of a little child. His conduct was clearly reprehensible. Evidence mounted up whenever Trump mounted the podium to brief the journalists. Media outlets repeatedly reported excerpts from Trumps interviews or briefings to instill that he is unfit for leadership. These media outlets seized every opportunity to highlight Trump's grave mistakes to prove that he is unfit to lead this free nation. The media gave special attention to Mattis's remarks when saying the American people have been without mature leadership. The media highlights the claim that Trump is good at ignoring others. They gave support from countless occurrences when Trump intentionally ignored questions from reporters and journalists for example. He further ignored all calls to allow peaceful protests and called protesters cleared forcibly from around the White House "terrorists". He is being insensitive and his comments lack compassion and empathy. The president has been practicing systematic racism, and racism never was absent from the American life. On one occasion, Trump said: "we like black people". This is an indication of white supremacy, and that black people are second-class citizens. He sounded unrealistic and off course when he described what is happening in America as "great". Trump claimed that what is happening is the best that could happen to the African Americans, the Hispanic Americans and other minorities in the U.S. Trump slammed D.C. mayor who is black as unfit for the job after naming the street that leads to the White House "Black Lives Matter Plaza". His comments about Floyd when saying "it is a great day for Floyd" caused outrage among African Americans in particular and the American public in general. Trump's continuous departure from reality continued in the midst of nationwide protests. The president does not speak or feel but the language of economy. On many occasions, he kept on repeating his sickening cliché "we have the strongest economy in the world" out of context. He has agendas which have nothing to do with the reality of what is going on in the country. For example, the president gave reason for the killing of George Floyd which is passing a fake $\$ 20$ bill in a neighborhood convenient store. On many occasions, the president of the free world praised dictators from around the world; he called Egyptian president Abdel-Fattah Alsisi "my favorite dictator", and he met with North Korean dictator Kim Jong-un several times and expressed appreciation of his personality and way of governance.

Eighth, the media outlets endlessly repeated phrases in support of protesters and in defiance of president Trump and his leadership. For example, "change is sentiment", "a sense of hope", "a man tortured to death", "those who want to maintain the status quo such as the police and the leadership", "sadistic murder of George Floyd", "aggressive policemen", "violation of civil rights and civil liberty", "Floyd is one unarmed black man among many killed by the police", "nine minutes he has been to the side walk with the knee on his neck", "calling the killing a national tragedy", and so forth. These phrases were detrimental for Trump's leadership and his political future.

Ninth, counterclaims and countervailing interviews received no significant attention or coverage from media outlets. Many images and news items went unnoticed since they do not serve the purpose of the media, and that the media were reluctant to show them; some of these include claims that Trump's supporters took to the streets fully armed with hand guns in some U.S. cities in support of Trump and his actions and policies; claims that Floyd showed resistance for arrest, and that he was intoxicated which forced the police to use excessive force that lead to his strangulation; Floyd's passing of the fake $\$ 20$ bill at a neighborhood convenient store which required police intervention after receiving a phone call from an employee at the store, and so forth.

\section{Conclusion}

Propagandist media not only managed to position president Donald Trump but also to frame him as a person who failed to live up to the expectations, hopes and needs of the American people as well as a person unfit for leadership. Several reporting techniques were used to entrench this attitude in society. 
While the U.S is being ravaged by the state of unrest and slashed with a surge of waves of protests, Trump, as usual, secluded himself away from his people watching the plight of his citizens unabashed by his awkward reactions to the murder of George Floyd as a result of police brutality and excessive use of power.

Americans believe now that they are ruled by an immature and incompetent leader who is incapable of drawing differences between invading other countries and draining out their resources for his own good and invading his own country by his own military. In addition, they believe that the incumbent president does not fit for leadership, and he is untrustworthy.

Trump's call for military intervention did elicit awkward reactions on behalf of the protesters. The protests over Floyd's death show little sign of slowing down, and it is very important for the media to report this to consolidate that the country is going through an anarchy and havoc. His protest response left not just people but also other heads of states speechless and astonished.

The division is now between the leadership and the public. This division appeared unredeemable. With the help of propagandist media, the division extends to the leadership and its officials who oppose Trump's present strange actions. The gap is widening, and Trump's rock solid coalition is on its way for extinction. Americans are anxiously waiting for the presidential elections in November hoping to avenge on the leadership that betrayed, deceived, and murdered them without showing any type of clemency and plummeted their economy and their spirits as well. Many Americans believe that Joe Biden is going to win the elections not because he is the better candidate but because American people want president Trump out.

\section{References}

Beaugrande, R. A., \& Dressler, W. U. (1981). Introduction to Text-linguistics. London \& New York: Routledge. https://doi.org/10.4324/9781315835839

Boyd-Barrett, O. (2003a). Doubt Foreclosed: US mainstream media and the attacks of September 11, 2001. In N. Chitty, R. Rush \& M. Semati (Eds), Studies in Terrorism: media scholarship and the enigma of terror, Penang: Southbound Press.

Crockett, D. (2003). George W. Bush and the Unrhetorical Rhetorical Presidency. Rhetoric and Public Affairs, 6, 465-486. https://doi.org/10.1353/rap.2003.0059

Davies, B., \& Harre. R. (1990). Positioning. Journal for the Theory of Social Behaviour, 21, 1-18.

Downing, J. (1980). The Media Machine. London: Pluto Press.

Fairclough, N. (1992). Discourse and Social Change. Cambridge: Polity Press.

Harre, R., Moghaddam, F. M., Pilkerton-Cairnie, T., Rothbart, D., \& Sabat, S. (2009). Recent advances in positioning theory. Theory \& Psychology, 19, 5-31. https://doi.org/10.1177/0959354308101417

Kellner, D. (1992). The Persian Gulf TV War. Boulder, CO: Westview Press.

Kernell, S. (1997). Going Public: New Strategies of Presidential Leadership (3rd ed.). Washington, D.C.: Congressional Quarterly Inc.

Knightly, Ph. (2002). The First Casualty. The war correspondent as hero and myth-maker from the Crimea to Kosovo. Baltimore, MD: Johns Hopkins University Press.

Mesthrie, R., Swann, J., Deumert, A., \& Leap, L. W. (2009). Introducing Sociolinguistics. Edinburgh: Edinburgh University Press.

Pratkanis, A. R., \& Aronson, E. (1991). Age of Propaganda: The Everyday Use and Abuse of Persuasion. New York: W. H. Freeman.

Ryfe, D. M. (2005). Presidents in Culture: The Meaning of Presidential Communication. New York: Peter Lang Publishing.

Taylor, Ph. (2003). Munitions of the Mind: A history of propaganda from the Ancient to the Present Era (3rd ed.). UK: Manchester University Press.

Tulis, J. (1987). The Rhetorical Presidency. Princeton: Princeton University Press. 


\section{Copyrights}

Copyright for this article is retained by the author(s), with first publication rights granted to the journal.

This is an open-access article distributed under the terms and conditions of the Creative Commons Attribution license (http://creativecommons.org/licenses/by/4.0/). 